\title{
Mercury in the Bottom Sediments of the Water Retention Reservoirs
}

\author{
M. Tarnawski ${ }^{1}$, N. Florencka ${ }^{2}$ and A. Baran \\ ${ }^{1}$ Department of Water Engineering 2 , University of Agriculture in Krakow, al. A. Mickiewicza 24/28, 30-059 Kraków, \\ Poland, rmtarnaw@cyf-kr.edu.pl \\ ${ }^{2}$ Faculty of Mining Surveying an Environmental Engineering, AGH University of Science and Technology al. A. \\ Mickiewicza 30, 30-059 Kraków, Poland, floren@agh.edu.pl \\ ${ }^{3}$ Department of Agricultural and Environmental Chemistry, University of Agriculture in Krakow, al. A. Mickiewicza 21, \\ 31-120 Krakow, Poland, Agnieszka.Baran@ur.krakow.pl
}

\begin{abstract}
In the environment, mercury undergoes constant changes and gets into soils or waters through atmospheric precipitation. It is quickly sorbed by mineral and organic colloids which occur in water and transported in the form of a suspension or accumulated in bottom sediment. Quality of sediments is an essential indicator of water pollution with this element. The aim of this paper was to an assessment of mercury content in bottom sediments of retention reservoirs in south-eastern Poland. The sediments were analyzed for mercury content. DMA-80 Mercury Analyzer was used for the analysis. The research results showed that average content of $\mathrm{Hg}$ in the majority of the studied bottom sediments did not exceed the geochemical background value, the sediments belonged to class 1 (unpolluted sediments). Evaluation of the state of sediments with the use of the geoaccumulation index and the pollution coefficient revealed moderate pollution of bottom sediments of the reservoirs in Rzeszów, Ożanna, Brzóza Stadnicka, Brzóza Królewska, Narożniki, Głuchów and considerable pollution of sediments from Rybnik and Bagna Rzeszowskie. Low mercury content in the studied sediments is generally related to lack of anthropogenic sources of this metal
\end{abstract}

Keywords: mercury, bottom sediments, geoaccumulation index, pollution coefficients

\section{Introduction}

Sediments accumulating at the bottom of watercourses and reservoirs have various composition, which depends on geological structure of a river basin, geomorphology of an area, climatic conditions and also on the way of management, use of river basin area and pollutants reaching waters. Bottom sediments are living and feeding grounds for many organisms. Polluted sediments lead to poisonings and diseases of aquatic species, thus putting people and animals that eat meat from fish in danger. In the environment, mercury undergoes constant changes and gets into soils or waters through atmospheric precipitation. It is quickly sorbed by mineral and organic colloids which occur in water and transported in the form of a suspension or accumulated in bottom sediment. Mercury bounded in bottom sediments may easily undergo remobilization, depending on environmental conditions. Both biotic and abiotic processes responsible for reduction and methylation of mercury can influence its mobilization. Quality of sediments is an essential indicator of water pollution with this element. The natural content of mercury in sediments does not exceed $0.05 \mathrm{mg}$ $\mathrm{kg}-1$, and in soils this content is within the range of $0.05-$ $0.3 \mathrm{mg} \cdot \mathrm{kg}-1$.

The aim of this paper was to an assessment of mercury content in bottom sediments of retention reservoirs in south-eastern Poland.

\section{Materials and Methods}

Samples of bottom sediments were taken from eight water bodies located in south-eastern Poland (Tab. 1). Sediment samples were taken from all the reservoirs, according to the following methodology. Three zones were established in a reservoir bowl: inlet (backwater), middle and outlet (near the dam) zone. 5-6 samples were taken from each zone and mixed in order to average the properties of sediments in samples representative of a given zone. Ekman sampler was used for obtaining 
Tab.1 Content and assestement of $\mathrm{Hg}$ in the bottom sediments $(\mathrm{mg} \cdot \mathrm{kg}-1)$

\begin{tabular}{|c|c|c|c|c|c|c|c|c|}
\hline $\begin{array}{l}\text { Reservoir } \\
\text { Method }\end{array}$ & $\begin{array}{l}\text { Bagna } \\
\text { Rzesz. }\end{array}$ & Rzeszów & Brzóza K. & Ożanna & Brzóza S. & Narożnik & Głuchów & Rybnik \\
\hline Mean & 0.158 & 0.084 & 0.041 & 0.065 & 0.048 & 0.020 & 0.030 & 0.170 \\
\hline $\begin{array}{l}\text { Geochemical } \\
\text { Background }\end{array}$ & \multicolumn{8}{|l|}{0.05} \\
\hline Index (Igeo) & 0.32 & 0.05 & -0.26 & -0.06 & -0.19 & -0.59 & -0.40 & 0.36 \\
\hline $\begin{array}{l}\text { Index of } \\
\text { pollution }(\mathrm{Cf})\end{array}$ & 3.16 & 1.67 & 0.82 & 1.30 & 0.97 & 0.39 & 0.59 & 3.40 \\
\hline $\begin{array}{l}\text { Polish } \\
\text { Geological } \\
\text { Institute }\end{array}$ & $\mathrm{II} * *$ & $\mathrm{I}^{*}$ & I & I & I & I & I & II \\
\hline
\end{tabular}

*I class - unpolluted sediments, no harmful effects of trace elements and toxic organic compounds on aquatic organisms are observed; **II class - sediments moderately polluted, harmful effect of trace elements on aquatic organisms occurs occasionally.

sediment samples. The sediments were analyzed for mercury content. After drying and crushing of the material, the amount of mercury in the samples was determined. DMA-80 Mercury Analyzer was used for the analysis. Geochemical method was used in the assessment of pollution of sediments with mercury. The following indicators were used in the paper: guidelines of the Polish National Geological Institute (Bojakowska, Sokołowska 1998), geoaccumulation index (Igeo) (Müller 1981) and pollution coefficients (Håkanson 1980).

\section{Results}

Table 1 presents average mercury contents in the examined sediments and their assessment according to geochemical indicators. The examined material varied significantly both within individual sections of a given reservoir and between the objects. The highest mercury contents were found in the Bagna Rzeszowskie reservoir where $0.158 \mathrm{mg} \cdot \mathrm{kg}-1 \mathrm{Hg}$ were noted and also in the Rybnik Reservoir where mercury content reached 0.181 mg · kg-1. Sediments coming from the Rzeszów Reservoir had similar values, slightly higher contents of the examined element were in the central section $(0.085$ $\mathrm{mg} \cdot \mathrm{kg}-1)$. The reservoir in Brzóza Królewska had extremely divergent amounts of the examined element, the outlet spot had 9 times more mercury than other sections. Sediment samples taken from the reservoir at Narożniki had similar mercury contents, amounts of $\mathrm{Hg}$ were increasing while moving away from the inlet. There was 2 times more mercury at the outlet than at the inlet to the reservoir. Similar tendencies of the mercury amount in the examined bottom material were noted in reservoirs in Głuchów and Brzoza Stadnicka. The obtained results do not diverge from other authors' research which showed that the mercury content in bottom sediments of retention reservoirs in Poland is on average between 0.07 and $0.18 \mathrm{mg} \cdot \mathrm{kg}-1$.

\section{Conclusions}

The research results showed that average content of $\mathrm{Hg}$ in the majority of the studied bottom sediments did not exceed the geochemical background value (Bojakowska, Sokołowska 1998), the sediments belonged to class 1 (unpolluted sediments). Only bottom sediments of the reservoirs in Rybnik and Brzóza K. were characterized with content corresponding to class 2 - average pollution with mercury. Evaluation of the state of sediments with the use of the geoaccumulation index and the pollution coefficient revealed moderate pollution of bottom sediments of the reservoirs in Rzeszów, Ożanna, Brzóza S., Brzóza K., Narożniki, Głuchów and considerable pollution of sediments from Rybnik and Bagna Rzesz. (tab. 1). Low mercury content in the studied sediments is generally related to lack of anthropogenic sources of this metal. Elevated contents of $\mathrm{Hg}$ in bottom sediments of the reservoirs in Rybnik and Bagna Rzesz. are related to a short distance to big urban agglomerations and industrial plants (the Rybnik Reservoir).

\section{Acknowledgements}

Scientific work financed the budget for science Research Grant No. N N305 295037 "Assestement of the possibility of agricultural use reservoir bottom sediments" (2009-2012)

\section{References}

Bojakowska, I., Sokołowska G. Geochemical purity classes of bottom sediments, Polish Geological Review, 1998; 46: 49-54 (in Polish)

Müller G. Die Schwermetallbelastung der Sedimenten des Neckars und seiner Nebenflüsse. ChemikerZeitung, 1981; 6: 157-168 (in German).

Håkanson L. An ecological risk index for aquatic pollution control. A sedimentological approach Water Research, 1980; 14: 975-1001. 